\title{
SHAPING OF SPATIAL STEEL ROD STRUCTURES BASED ON A HYPERBOLIC PARABOLOID
}

\section{J. DZWIERZYNSKA ${ }^{1}$}

\begin{abstract}
Summary: The aim of the study was to develop a practical approach to parametric shaping of spatial steel rod structures formed based on a hyperbolic paraboloid. This design approach was realized by application of designing tools working in environment of Rhinoceros 3D, that is its plug-in Grasshopper for geometric modelling and Karamba 3D for structural analysis. The goal of this research was to elaborate an universal scripts in order to create rod structures ' models of various forms and grid patterns, as well as evaluating their structural behaviour dependently on various boundary conditions. The optimisation criterion was the minimum mass and deflection. Several proposals of coverings by means of single layer grid structures were presented and analysed to choose the best solution. The rod structures generated based on a hyperbolic paraboloid turned out to be structures with good static properties, so may be an interesting proposals to cover large areas.
\end{abstract}

Keywords: parametric modeling, structural analysis, optimization, Grasshopper, Karamba 3D, hyperbolic paraboloid, rod structure, ruled surface

PhD., Eng., Rzeszow University of Technology, Faculty of Civil, Environmental Engineering and Architecture, Al. Powstancow Warszawy 12,35-959 Rzeszow, Poland, e-mail: joladz@prz.edu.pl 


\section{INTRODUCTION}

The complexity of contemporary free-form architectural objects has been a driving force for development of new digital design methods over the last decade. Applied mathematics and particularly geometry have initiated the development of a comprehensive framework for complex modeling, especially smooth modeling based on Non-Uniform Rational B-Splines (NURBS). Flexible shapes of NURBS curves, controlled during the design process, constituted a base for generation of various digital parametrically changeable topological forms. In turn, digital parametric modeling has profoundly changed the processes of design and construction.

In parametric design a geometric form is shaped not by declaration of its shape and structure, but by parameters and equations describing them [1,2]. Digital environment, on the one hand gives much freedom in shaping free forms, on the other hand allows designers to use computer software for optimization and simulation of projects. Due to this fact, it helps to make a right decision at the early stage of designing, whereas a digital model becomes a single source of information which can be generated, controlled and managed by a designer [3]. Along this line of thought the paper discusses a novel parametric approach to shaping of spatial steel rod structures which can be structures of building coverings. They are formed basing on a hyperbolic paraboloid surface. Hyperbolic paraboloid surfaces due to their positive static properties are well established in the area of shells. They are also easy-to-use elements for architectural design and offer many interesting design possibilities [4]. Due to this fact, a hyperbolic paraboloid thanks to both its geometric and aesthetic features is worth consideration as a base form for modeling of rod structures. The rod structures which form grid shells are usually long span structures composed of a lattice of single layer or multilayer members. They can be used in various both vertical and overhead applications as they have great potential to form impressive structures $[5,6]$. Recently, in the parametric environment, optimization has been the subject of interest for many researchers, however, most contributions in this field are concerned with the optimization of geometric properties of meshes approximating free-form structures by planar faces. Our approach to shaping of rod structures is to link geometric modeling of grid spatial forms with their structural analysis and optimization. The flexible scripts elaborated by us in order to describe geometric forms are converted into simulation 
models to perform structural analysis. The simulation enables us to evaluate various spatial grid shapes, as well as to select an optimal design solution meeting established criteria. We analyse rod structures based on a hyperbolic paraboloid surface composed of four repetitive modules. Our comparative criterion to create the roof structures is the minimum mass and deflection.

\section{MATERIALS AND METHODS}

\subsection{CHARACTERISTICS OF THE SOFTWARE APPLIED FOR MODELLING AND CALCULATIONS}

Thanks to the application of the new digital design tools for creating design representations that change in relation to parameters new forms can be created, as well as they can be examined much more comprehensively. The design approach to parametric modelling of spatial rod structures proposed in this research is realized by utilisation of Grasshopper, a parametric plug-in of the 3D modelling software Rhinoceros. The structural analysis is carried out using Karamba 3D, whereas the optimisation issues by means of Galapagos, which work in the same Rhinoceros 3D environment. Grasshopper is one of the most commonly used generative design editors in architecture, which enables to create very complicated geometric forms. On the other hand Karamba 3D combines parameterized complex geometric forms, load calculations and finite element analysis.

\subsection{GEOMETRIC PROPERTIES OF A HIPERBOLIC PARABOLOID SURFACE}

Hyperbolic paraboloids are doubly ruled surfaces. Due to their positive static properties, which allow the construction of shells with large span, as well as possibility of various arrangements of single shells in compound ones, they offer many interesting complex design possibilities. Due to this fact a hyperbolic paraboloid can always constitute an important basic shape for various interesting, complex architectural forms. 
A hyperbolic paraboloid is a saddle surface and it can be generated both as a translational surface and as a ruled surface. For the need of the creation of its parametric model, we consider a hyperbolic paraboloid as a ruled surface, the surface composed of straight rulings. These rulings can be established by connecting proper corresponding points of two generating lines, which are surface's directrices $[3,6]$. In order to create Grasshopper's algorithms, a hyperbolic paraboloid surface defined in a spatial system $x, y, z$ should be described by two parameters $(u, v)$, which determine its shape. We start parametric modelling of a hyperbolic paraboloid from establishing series of the same number of points on two arbitrary skew straight lines. The rulings join lines' points which correspond to the same parameter value along direction $u$ (here direction $u$ is the same as direction $x$ ). If all proper pairs of points included in the input straight lines are joined by straight line segments, a strip of a hyperbolic paraboloid can be obtained, Fig1. Such an unit surface can be a module for creating complex roof structures. Various shapes of the roofs compound of different elements of the hyperbolic paraboloid surface are presented in $[8,9]$.

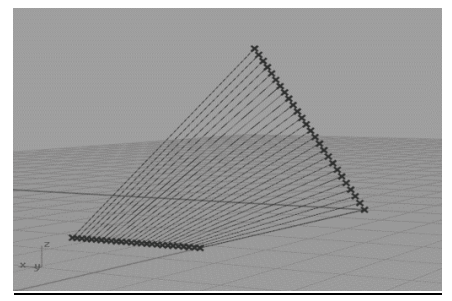

Fig. 1. Creation of the hyperbolic paraboloid's module.

Further, we consider the surface compound of four similar modules of a hyperbolic paraboloid. The modules can be arranged and joined in various ways. Due to this fact, we have distinguished four compound forms: A, B, C, D, Fig.2. These compound surface forms can constitute the bases for placing nodes of the steel rod structures.

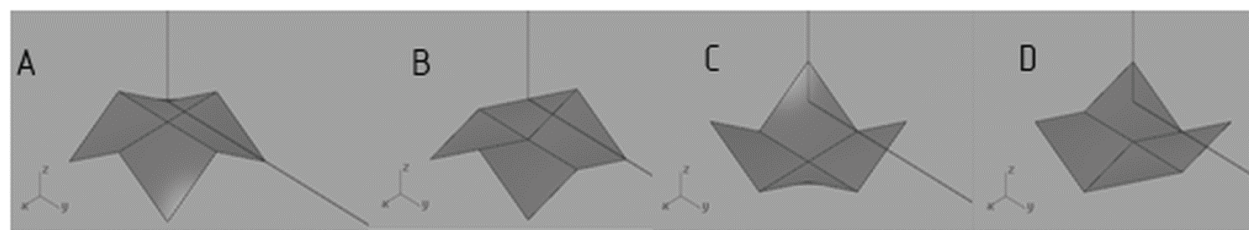

Fig. 2. The compound surfaces of a hyperbolic paraboloid used for formation of spatial lattices. 


\section{RESULTS}

\subsection{ChARACTERISTICS OF THE STRUCTURAL MODELS}

In our research, several representative spatial rod structures formed basing on the hyperbolic paraboloid surfaces presented above have been subjected to structural analysis. For each grid structure three various mesh patterns were applied. Due to the fact that, triangular meshes are more rigid and stronger than others, as well as they can approximate easily free form shapes, we have chosen this kind of structures for further considerations. The rectangular projection of each grid pattern is presented in the Fig.3.

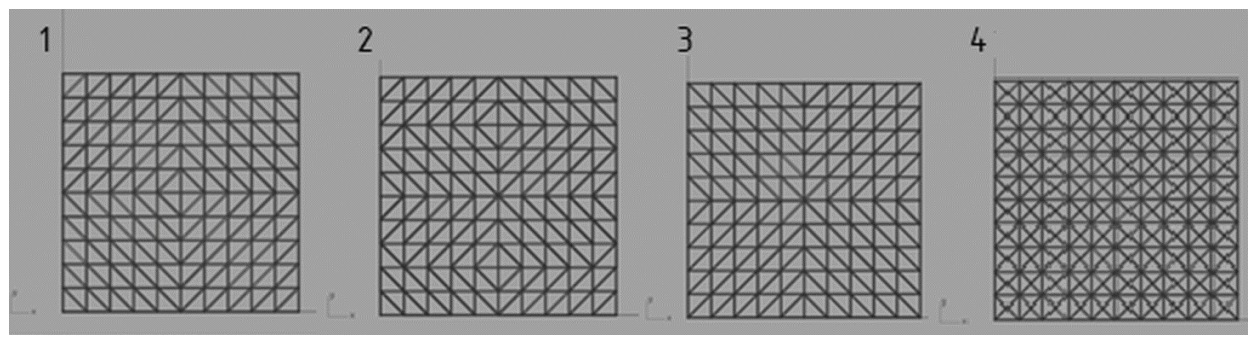

Fig. 3. Considered types of grid patterns.

Each of the considered patterns constituted a triangular mesh with the same division into $u=10$ segments along direction $u(x)$ and the division into $\mathrm{v}=10$ segments along direction $v(y)$. Due to this fact each the rod structure of the pattern 1, 2 and 3 was composed of 121 nodes, 200 faces being triangles and 320 rods, whereas the structure 4 was composed of 244 nodes, 400 faces being triangles and 620 rods.

Taking into account geometric shape of the base compound surface (A, B, C or D), as well as the possible grid pattern $(1,2,3,4)$, it could be achieved several various types of spatial rod structures. Moreover, due to the fact that each type of the structure was modeled parametrically by Grasshopper the range of possible structural forms for the each type increased. We have applied the pattern 1 for surface A and surface C, whereas the pattern 2 for surface B and D. However, the patterns 3 and 4 were applied for each kind of surfaces: A, B, C, D. It has been assumed similar support system for all rod structures, that is four corner supports at boundary nodes. Moreover, it has been assumed that each grid structure covers a square place with the border edges equal to 10.0 $\mathrm{m}$, as well as each grid structure is of the same height of $2.0 \mathrm{~m}$ or $4.5 \mathrm{~m}$. 
Representative examples of the rod structures of types: A3, B4, C1, D2 are presented respectively in the figures Fig.4, Fig.5, Fig.6 and Fig.7.
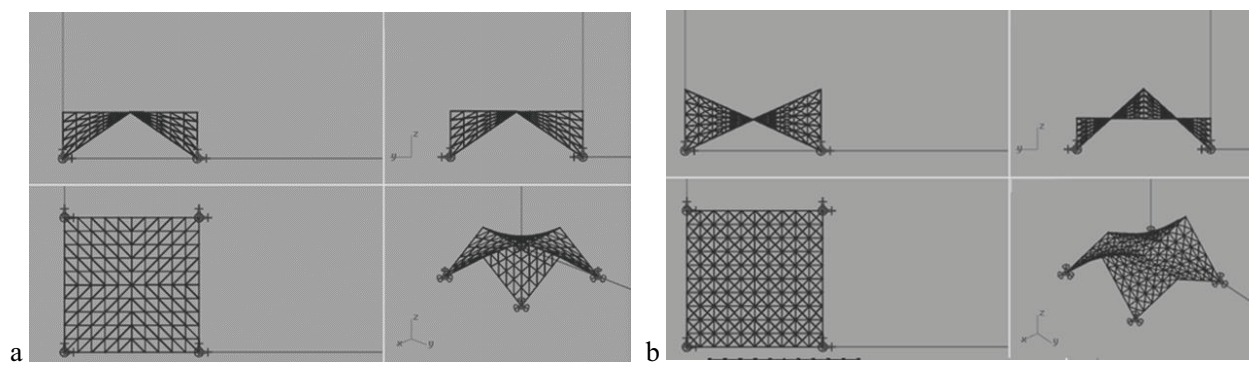

Fig. 4. Representation of the grid structure of the type A3, B4.
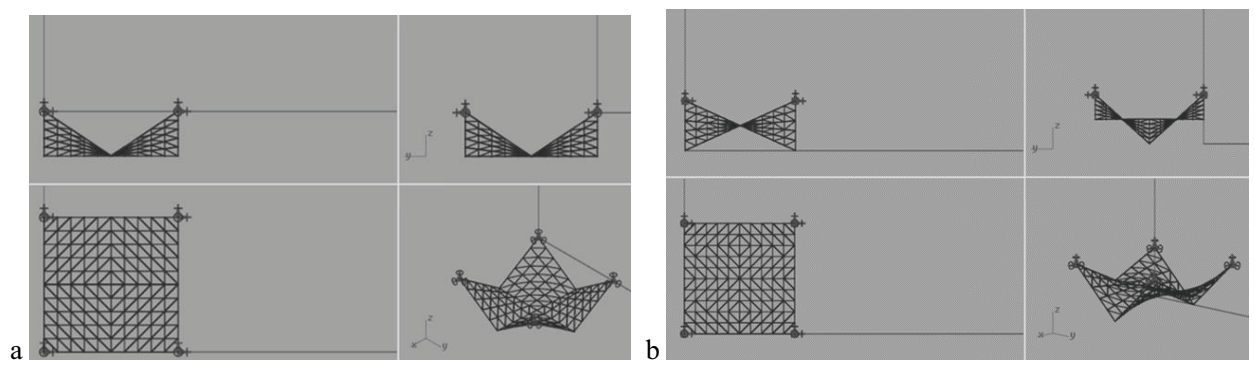

Fig. 5. Representation of the grid structure of the type C1, D2.

\subsection{ANALYSIS OF THE STATIC BEHAVIOR OF THE SPATIAL ROD STRUCTURES}

In order to perform structural analysis by means of Karamba 3D, parametric geometric models of each grid structure prepared by means of Grasshopper's generative algorithmic modelling tool were converted into structural models. Due to the fact that FEM simulation represents physical objects as a collection of discrete components or elements, the geometry of rod structures was presented by meshes. In order to study of the structural behaviour the following characteristics have been considered: the way of supporting of the structure - four corner supports, material - steel resistant against stress (S275), cross sections - circular hollows, assembly, as well as external loads properties [5].

The first simulation by means of Karamba 3D was performed for 24 types of rod structures when being subjected to the dead load. The dead load which acted in negative $z$ direction constituted the self-weight of the spatial steel grid structure. The pipes' cross section diameters were assumed to be 
of $101.6 \mathrm{~mm}$, whereas the pipes' wall-thickness of $36 \mathrm{~mm}$. The structural behaviour was analysed both for the steel rod structures of $2.0 \mathrm{~m}$ height and of $4.5 \mathrm{~m}$ height.

We have taken into account the minimal mass of the structure and maximum displacement both at the end-points and mind-points of the mesh elements as the main criteria for assessing structural stability. The achieved results of the performed structural analysis are presented in Table1 and Table 2. Table 3.

Table 1. Results of the structural analysis of the rod structures with the grid pattern 1 and 2 .

\begin{tabular}{|c|c|c|c|c|c|}
\hline Surface's type & $\begin{array}{c}\text { Pattern of a } \\
\text { grid }\end{array}$ & $\begin{array}{c}\text { Height of the } \\
\text { structure }[\mathrm{m}]\end{array}$ & $\begin{array}{c}\text { Rods' radius/ } \\
\text { thickness }[\mathrm{mm}]\end{array}$ & $\begin{array}{c}\text { Mass of the } \\
\text { structure }[\mathrm{kg}]\end{array}$ & $\begin{array}{c}\text { Maximum } \\
\text { displacement } \\
{[\mathrm{mm}]}\end{array}$ \\
\hline A & 1 & 2.0 & $101.6 / 3.6$ & 3211.26 & 0.8 \\
\hline A & 1 & 4.5 & $101.6 / 3.6$ & 3455.57 & 0.3 \\
\hline B & 2 & 2.0 & $101.6 / 3.6$ & 3180.55 & 4.8 \\
\hline B & 2 & 4.5 & $101.6 / 3.6$ & 3362.07 & 2.3 \\
\hline C & 1 & 2.0 & $101.6 / 3.6$ & 3211.26 & 0.8 \\
\hline C & 1 & 4.5 & $101.6 / 3.6$ & 3455.57 & 0.3 \\
\hline D & 2 & 2.0 & $101.6 / 3.6$ & 3190.55 & 4.8 \\
\hline D & 2 & 4.5 & $101.6 / 3.6$ & 3362.07 & 2.3 \\
\hline
\end{tabular}

Table 2. Results of the structural analysis of the rod structures with the grid pattern 3 .

\begin{tabular}{|c|c|c|c|c|c|}
\hline Surface's type & $\begin{array}{c}\text { Pattern of a } \\
\text { grid }\end{array}$ & $\begin{array}{r}\text { Height of the } \\
\text { structure [m] }\end{array}$ & $\begin{array}{c}\text { Rods' radius/ } \\
\text { thickness [mm] }\end{array}$ & $\begin{array}{c}\text { Mass of the } \\
\text { structure [kg] }\end{array}$ & $\begin{array}{c}\text { Maximum } \\
\text { displacement } \\
{[\mathrm{mm}]}\end{array}$ \\
\hline A & 3 & 2.0 & $101.6 / 3.6$ & 3257.73 & 0.5 \\
\hline A & 3 & 4.5 & $101.6 / 3.6$ & 3665.27 & 0.4 \\
\hline B & 3 & 2.0 & $101.6 / 3.6$ & 3202.09 & 2.7 \\
\hline B & 3 & 4.5 & $101.6 / 3.6$ & 3415.93 & 1.4 \\
\hline C & 3 & 2.0 & $101.6 / 3.6$ & 3257.73 & 0.5 \\
\hline C & 3 & 4.5 & $101.6 / 3.6$ & 3665.27 & 0.5 \\
\hline D & 3 & 2.0 & $101.6 / 3.6$ & 3202.09 & 2.7 \\
\hline D & 3 & 4.5 & $101.6 / 3.6$ & 3415.93 & 1.4 \\
\hline
\end{tabular}


Table 3. Results of the structural analysis of the rod structures with the grid pattern 4 .

\begin{tabular}{|c|c|c|c|c|c|}
\hline Surface's type & $\begin{array}{c}\text { Pattern of a } \\
\text { grid }\end{array}$ & $\begin{array}{c}\text { Height of the } \\
\text { structure }[\mathrm{m}]\end{array}$ & $\begin{array}{c}\text { Rods' radius/ } \\
\text { thickness [mm] }\end{array}$ & $\begin{array}{c}\text { Mass of the } \\
\text { structure [kg] }\end{array}$ & $\begin{array}{c}\text { Maximum } \\
\text { displacement } \\
{[\mathrm{mm}]}\end{array}$ \\
\hline A & 4 & 2.0 & $101.6 / 3.6$ & 4496.91 & 0.4 \\
\hline A & 4 & 4.5 & $101.6 / 3.6$ & 4938.05 & 0.4 \\
\hline B & 4 & 2.0 & $101.6 / 3.6$ & 4453.28 & 3.0 \\
\hline B & 4 & 4.5 & $101.6 / 3.6$ & 4744.95 & 1.6 \\
\hline C & 4 & 2.0 & $101.6 / 3.6$ & 4496.91 & 0.4 \\
\hline C & 4 & 4.5 & $101.6 / 3.6$ & 4938.05 & 0.4 \\
\hline D & 4 & 2.0 & $101.6 / 3.6$ & 4453.35 & 2.9 \\
\hline D & 4 & 4.5 & $101.6 / 3.6$ & 4745.29 & 1.6 \\
\hline
\end{tabular}

Analysing the achieved results we can state that the structure of each type is stable. However, the minimal mass of the rod structure was obtained in the case of the structures with pattern 1 or 2 . Due to the fact that the structures with the pattern 4 are relatively heavy, they have been excluded from further considerations. Next, the structure A1 with good structural characteristic (Table 1) has been chosen for further analysis to check its behaviour when subjected to the load combination of selfweight and external forces. Due to this fact, in the second structural analysis performed by us, it was assumed that the structure was covered by glass panels and it was subjected to the snow pressure of $1,3 \mathrm{KN} / \mathrm{m}^{2}$ and wind pressure of $1 \mathrm{KN} / \mathrm{m} 2$ being applied in various load combinations. Karamba's optimisation results for the worst load combination scenario is presented in Fig.6. The results shows that maximum displacement increases under the environmental loads, however the structure is still stable.
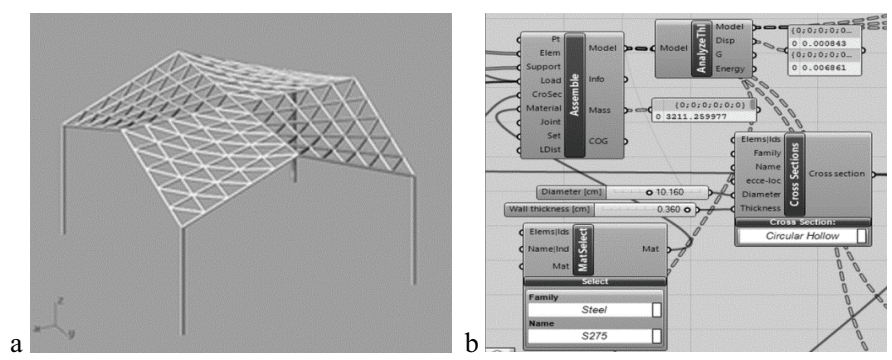

Fig. 6. Results of the structural analysis for the worst load combination scenario: a- a considered structure, b- results. 
The considered steel rod sructures can constitute modules for more complex rod forms. The examples of such compound structures with various arrangements of the moduls and various grid patterns are presented in Fig 7.
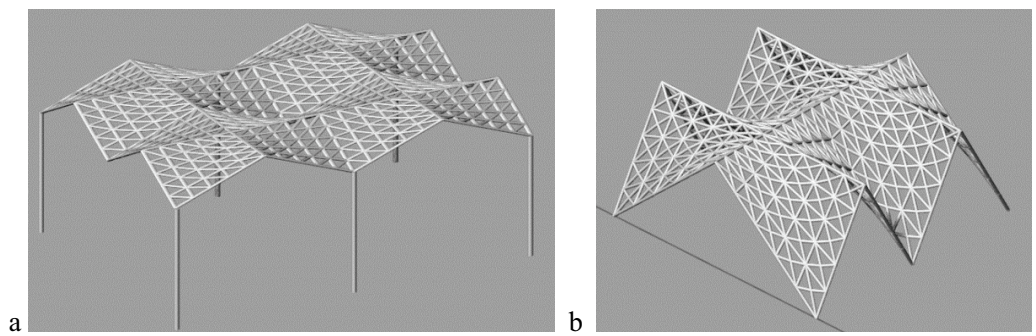

Fig. 7. Modular structures of various topology: a-with the pattern 1, b-with the pattern 4 .

Their structural behaviour is partly dependent on the behaviour of the single module. However, it can be establish by modification of the scripts for structural analysis utilized for a single module. This modification should include the number of modules and supports applied, as well as their arangements and location.

\section{CONCLUSSIONS}

The conducted research showed a practical framework of parametric approach to shaping steel rod structures based on a hyperbolic paraboloid. Although a hyperbolic paraboloid surface is used as a base surface for various coverings in building industry, the present study is innovative for some reasons. This is due to the fact that the elaborated approach consists in testing mechanical performance of structures in an initial stage of design, as well as it uses the set of tools completely outside of the scope of traditional structural engineering software. Grasshopper, and Karamba 3D utilizing the same modelling software- Rhinoceros 3D seemed to be especially useful.The elaborated scripts for parametric shaping of steel rod structures created basing on the hyperbolic paraboloid surface work well. They allowed us to create various geometric types of rod structures and analyze their structural performance using various boundary conditions. Our research showed that the grid pattern of the rod structure affected load bearing capacity of the structure as it influenced the distribution of loads along its rods. Rod structures generated based on the hyperbolic paraboloid shape are structures with good static properties and may be an interesting proposals to cover large areas. 


\section{REFERENCES}

1. S. Bhooshan, "Parametric design thinking; A case study of practice-embedded architectural research", Design Studies. 52, 115-143, 2017

2. T. Wortmann, B. Tuncer, "Differentiating parametric design :Digital Workflows in Contemporary Architecture and construction”, Design. Studies. 52 173-197, 2017

3. H. Pottman, A. Asperl, M. Hofer, A. Kilian, Architectural Geometry; Bentley Institute Press: Exton, PA, USA, 2007

4. T. Tarnai, Spherical Grids of triangular network, Acta Technica. Academiae. Scientiarum. Hungaricae, 76,307338, 1974

5. J. Brodka, Structural coverings, Arkady, Warsaw 1985, (in Polish)

6. S. Krivoshapko, V. Ivanov, Encyclopaedia of Analytical Surfaces; Springer International Publishing, Switzerland 2015

7. S. Przewlocki, Descriptive Geometry in Construction, 1st ed.; Arkady: Warsaw, Poland, pp. 57-209, ISBN 83-213-3036-3, 1982

8. J. Dzwierzynska, A. Prokopska, "Pre-rationalized parametric designing of roof shells formed by repetitive modules of Catalan surfaces", Symmetry, 10,105, 2018, 


\section{LIST OF FIGURES AND TABLES:}

Fig. 1. Creation of the hyperbolic paraboloid's unit.

Rys.1. Tworzenie jednostkowego elementu hiperboloidy parabolicznej.

Fig. 2. The compound surfaces of a hyperbolic paraboloid used for formation of spatial lattices.

Rys.2. Złożone powierzchnie paraboloidy hiperbolicznej do formowania przestrzennych siatek

Fig. 3. Considered types of grid patterns.

Rys.3. Rozważane rodzaje wzorów siatek.

Fig. 4. Representation of the grid structure of the type A3, B4.

Rys.4. Odwzorowanie siatkowej struktury typu A3, B4.

Fig. 5. Representation of the grid structure of the type C1, D2.

Rys.5. Odwzorowanie siatkowej struktury typu C1, D2.

Fig. 6. Results of the structural analysis for the worst load combination scenario: a- a considered structure, bresults.

Rys.6. Rezultaty analizy strukturalnej dla najbardziej niekorzystnej kombinacji obciążeń: a-rozważana struktura, b-wyniki.

Fig. 7. Modular structures of various topology: a-with pattern 1, b-with pattern 4.

Rys.7. Struktury modularne o różnej topologii: a- ze wzorem 1, b-ze wzorem 2.

Tab. 1. Results of the structural analysis of the rod structures with the grid pattern 1 and 2.

Tab. 1. Rezultaty analizy strukturalnej struktur prętowych ze wzorem siatki 1 i 2.

Tab. 2. Results of the structural analysis of the rod structures with the grid pattern 3 .

Tab. 2. Rezultaty analizy strukturalnej struktur prętowych ze wzorem siatki 3.

Tab. 3. Results of the structural analysis of the rod structures with the pattern 4 .

Tab. 3. Rezultaty analizy strukturalnej struktur prętowych ze wzorem siatki 4. 


\section{KSZTALTOWANIE PRZESTRZENNYCH STALOWYCH KONSTRUKCJI PRETOWYCH NA BAZIE PARABOLOIDY HIPERBOLICZNEJ}

Keywords: modelowanie parametryczne, analiza strukturalna, Grasshopper, Karamba 3D, paraboloida hiperboliczna, struktura prętowa , powierzchnia prostokreślna

\section{STRESZCZENIE:}

W ciągu ostatniej dekady projektowanie parametryczne w architekturze i budownictwie zyskuje coraz większą popularność. W artykule prezentuje się parametryczne podejście do kształtowania przestrzennych stalowych struktur prętowych. Racjonalne projektowanie tego rodzaju struktur wynikające z analizy geometrycznej, topologicznej i strukturalnej przedstawia się na przykładzie siatek przestrzennych utworzonych na bazie hiperboloidy parabolicznej .

Modelowanie parametryczne konstrukcji proponuje się w oparciu o program Rhinoceros 3D oraz jego parametryczną wtyczkę Grasshopper. Analizę strukturalneą przeprowadza się w oparciu o wtyczkę Karamba 3D. Powierzchnią bazową do kształtowania geometrii przestrzennych struktur kratowych, na której rozmieszczono węzły jednowarstwowej siatki, jest powierzchnia utworzona $\mathrm{z}$ regularnych modułów będących wycinkami hiperboloidy parabolicznej. Analizie poddano struktury prętowe $\mathrm{z}$ rur stalowych o różnej topologii zakładając, że każda ze struktur stanowi konstrukcję przekrycia nad kwadratową powierzchnią o polu równym $100 \mathrm{~m}^{2}$.

W programie Grasshopper utworzono algorytmy opisujące geometrię oraz topologię rozważanych struktur kratowych. Na podstawie modeli geometrycznych opracowano ich modele strukturalne. Dla każdego z czterech sposobów ułożenia prętów siatki $(1,2,3,4)$ przeanalizowano modele strukturalne utworzone na bazie czterech różnych form powierzchniowych $(\mathrm{A}, \mathrm{B}, \mathrm{C}, \mathrm{D}) \mathrm{z}$ czterema punktami podparcia przyjętymi w węzłach zewnętrznych siatki. Na wstępie przeprowadzono analizę strukturalną każdego modelu przekrycia przy obciążeniu ciężarem własnym. Analizy dokonano dla struktur o wysokości $2 \mathrm{~m}$ oraz 4,5 m przyjmując wstępnie pręty w postaci rur o średnicy $10,16 \mathrm{~cm}$ i grubości ścianek równej $0,36 \mathrm{~cm}$. Wybrano strukturę A1 jako strukturę o dobrej charakterystyce (małym odkształceniu i małej masie). Dla powyższej struktury przeprowadzono analizę statyczną pierwszego rzędu uwzględniając obciążenia stałe i zmienne oraz dokonano wymiarowania. Obciążenie stałe stanowiło obciążenie własne będące sumą ciężaru konstrukcji kratowej oraz ciężaru pokrycia w postaci paneli szklanych, natomiast obciążenie zmienne obciążenie od śniegu oraz wiatru. Najbardziej niekorzystną kombinacją obciążeń okazała się kombinacja uwzględniająca obciążenia stałe oraz zmienne od śniegu oraz wiatru.

Parametryczne projektowanie $\mathrm{z}$ jednoczesnym wdrożeniem analizy strukturalnej $\mathrm{w}$ fazie wstępnej projektowania pozwala na racjonalne kształtowanie konstrukcji. Opracowane w pracy skrypty do parametrycznego kształtowania stalowych konstrukcji prętowych działają dobrze i wydają się być szczególnie użyteczne, gdyż umożliwiają tworzenie modeli geometrycznych różnorodnych struktur prętowych oraz szybkie analizowanie ich właściwości statycznych przy użyciu różnych warunków brzegowych. Badania pokazały, jak topologia siatek analizowanych konstrukcji prętowej wpływa na nośność konstrukcji oraz pozwoliły na wybór najlepszego rozwiązania. Hiperboloida paraboliczna jest powierzchnią minimalną o ciekawym kształcie, jednak stosowaną w budownictwie głównie do kształtowania konstrukcji żelbetowych. Badania wykazały że struktury prętowe utworzone w oparciu o hiperboloidę paraboliczną mają nie tylko duże walory estetyczne ale również dobrą charakterystykę statyczną, zatem przedstawione w pracy rozwiązania konstrukcyjne mogą stanowić ciekawą propozycję przekryć budowlanych. 